\title{
Article
}

\section{Driving Innovation through Energy Efficiency: A Russian Regional Analysis}

\author{
Alexander Melnik ${ }^{1}\left(\mathbb{D}\right.$, Irina Naoumova ${ }^{2}$, Kirill Ermolaev $^{1}(\mathbb{D})$ and Jerome Katrichis ${ }^{2, *(\mathbb{D})}$ \\ 1 Department of Innovation and Investment, Kazan (Volga Region) Federal University, 420008 Kazan, Russia; \\ amelnik21@gmail.com (A.M.); Ermolaev.kirill.a@gmail.com (K.E.) \\ 2 Department of Management, Marketing and Entrepreneurship, University of Hartford, \\ West Hartford, CT 01617, USA; naoumova@hartford.edu \\ * Correspondence: katrichis@hartford.edu; Tel.: +1-860-768-4760
}

Citation: Melnik, A.; Naoumova, I.; Ermolaev, K.; Katrichis, J. Driving Innovation through Energy Efficiency: A Russian Regional Analysis.

Sustainability 2021, 13, 4810 .

https://doi.org/10.3390/su13094810

Academic Editors: Anshu Arora, John R. McIntyre and Amit Arora

Received: 4 March 2021

Accepted: 16 April 2021

Published: 25 April 2021

Publisher's Note: MDPI stays neutral with regard to jurisdictional claims in published maps and institutional affiliations.

Copyright: (c) 2021 by the authors. Licensee MDPI, Basel, Switzerland. This article is an open access article distributed under the terms and conditions of the Creative Commons Attribution (CC BY) license (https:// creativecommons.org/licenses/by/ $4.0 /)$.

\begin{abstract}
Recent literature on energy efficiency focuses on the issues of energy security and options for reducing energy consumption. Measuring energy efficiency properly and forecasting future needs is critical to the energy policies of any country, especially given the importance of sustainability in their economic development. The role innovation plays in improving energy efficiency is well researched. There is a gap in examining an opposite relationship. That is, where energy efficiency becomes a critical factor for fueling innovation. This impact can occur within a company, a region, a nation or on an international level. Here we show that regions could motivate business innovations through policies requiring energy efficiency. Based on observations from a number of regions of an emerging economy, we show that energy efficiency impacts innovation. As a side effect it can contribute to export increases, which in turn can improve regional attractiveness for investors. We believe that the spiral development of the relationship between energy efficiency and innovation used as a strategy could become sustainable.
\end{abstract}

Keywords: energy efficiency; innovation; national competitiveness; sustainability

\section{Introduction}

Energy resources are a critical element in the development of the global economy [1-3]. While well developed nations are concerned mostly about environmental protection, and transfer to a green energy economy [4], less developed nations focus on cost efficient ways to grow based on cost saving technologies in industry, agriculture, and services [5]. In developing and emerging markets, energy cost is often a significant portion of product cost [6]. Thus, business policies in such economies focus on modernization, production cost reduction, improving competitiveness on a global scale, and the use of modern technologies and energy efficient equipment [7,8]. Some policies focus on energy saving campaigns [9], others advocate nationwide energy savings plans [10] and even the role of liberalization and industry restructuring for increased energy savings [11].

While less developed and emerging economies have slightly different objectives than developed ones, all are interested in developing possible ways of measuring and forecasting energy efficiency. Determining the relationship of energy efficiency with factors critical to driving economic development and improvement is also important. This is closely related to strategic management and competitive advantage issues [12-14]. Countries, keen to develop industries attract multinational corporations by promising cheap resources, including energy. Accessible and reasonably priced energy and policies supportive of energy efficiency and innovation play a significant role in improving the attractiveness of countries for multinational companies' (MNC) operations [15]. In both well-developed and less-developed economies, and others, energy efficient new technologies are critical for implementing competitive strategies $[12,16,17]$. Due to limited energy sources, current 
energy price volatility, and growing dependence on innovative technologies [18] the role of energy efficiency in regional and national competitiveness will increase.

Uneven energy resource distribution makes some countries highly dependent on external sources of supply. Monopoly of a supply of energy can be very painful for the budget of a country and, as a result, retard economic growth. Europe has developed a number of policies [19-21] to diversify energy inflows and prevent dependence on just one or a few supply sources. Europe has also placed a high priority on both energy security and energy efficiency. Methodologies for measuring and forecasting energy efficiency are widely discussed in the literature [22,23]. Additionally, a number of articles and reports on industry developments, and economic growth in an energy crisis era have appeared recently [24-26]. The environmental impact of energy policies has also been addressed, primarily in research derived from data from developed economies [27]. The rational use of energy resources, their preservation and conservation, where possible, and minimization or even compensation of negative impact on nature and the environment are considered to be among key factors of such an approach. Renewable and green energy have gained more attention recently [28] and added to the policies of diversification of energy resources. This has led to the emergence of new products, new services and even new industries [29]. Therefore, on a state or regional level, policies supporting the development, implementation and dissemination of "energy-efficient innovations" are typically seen as a part of a long-term focus on economic growth.

While the impact of innovation on energy efficiency is well researched, the opposite relationship-the impact of regional energy efficiency policies on innovation is clearly underresearched. The literature review confirms that, in spite of differences in approach and methods, researchers agree on the importance of energy conservation and energy efficiency for economic growth [30-32]. Most notably, researchers seem to agree on the critical role of innovations in achieving a desirable level of energy efficiency [33-35]. We expect that an opposite relationship is also true. That is, we propose that an increase in regional energy efficiency also facilitates the innovation process.

Scholarly treatments of energy efficiency revolve primarily around two approaches, a strategic approach and a tactical approach. The tactical approach to increasing energy efficiency is based on countries or regions attempting to copy best existing practices $[36,37]$. Clearly, benchmarking is one approach to achieving a high level of energy efficiency.

A strategic approach is used to satisfy a more dynamic requirement for energy efficiency. Because desired efficiency levels are greater, current technology and even best organizational practices would not be sufficient in the future to achieve the needed prospective energy efficiency level. New technologies and policies need to be created [38] to meet these more advanced requirements. Obviously, globalization of the World economy and growing international competition make efficiency requirements even harder to achieve. This focus on efficiency requirements tends to steer the focus of any country towards the strategic approach. Thus, energy conservation and energy efficiency goals initiate future innovations. Among practical examples connecting energy policies with future innovations is the Chinese government program, "Top 10,000," and the international, "Energy Star" program. Although the need for research in this area is clear to practitioners, the scholarly community has not seemed to agree on mechanisms of this impact on a regional or national level. There is no systematic vision and understanding of the impact of energy saving and energy efficiency policies on regional economic development and competitiveness. Thus, the goal of this study is to uncover the mechanisms of the relationship between energy saving and energy efficiency on innovation in Russia's regions. It will be shown that the relationships are robust in both directions. We will show that while innovations enhance energy efficiency, energy efficiency as a result of regional business policies positively impacts innovations. Additionally, as a side effect, it also positively affects regional exports. While the research is limited by a single country analysis and its possible replication in other countries is not provided here, the results could be applied by policymakers in Russia and may be useful to other countries. 


\section{Relationships between Energy Efficiency and Innovations}

The literature investigates relationships between energy efficiency and innovation on a national, regional, municipal and company level $[39,40]$. For the purpose of our research, we focus on energy efficient innovations. On a national level, a number of factors impact both energy efficiency and innovation. These include changing oil prices [40], the export/import orientation of a national economy [41,42], the speed of and obstacles to technology transfer [43], foreign direct investment policies and flows, levels of competition [44], international trade and access to imports from technologically developed countries [45], and participation of end-users in the process of developing energy-efficient innovations [46]. At the same time, a number of authors prove that an effective national policy facilitates innovations within private companies in the energy sector, thereby strengthening the competitiveness of the national economy in the long run. In his study, Urpelainen [42] argues that an export driven country would have a strong need for policies supporting and facilitating energy efficiency innovation as they increase national competitiveness. In addition, Lipp [47] confirms that the energy related policies in Denmark and Germany were strongly influenced by the needs of their developing exporting industries. Costantini and Crespi [48] have provided empirical support for a positive relationship between environmental regulatory requirements and increased exports of new technologies in the energy sector. Thus, environmental regulations become a kind of mechanism for facilitating environment-focused technology developments, which could be later exported to other interested countries. This also corresponds with Porter and Van der Linde [49], where environmental regulations are seen as a significant source of competitive advantages for a national economy. The authors justify that harder national environmental requirements would lead to increased exports of environmentally-focused technologies. Similarly, assuming it is true for the energy sector, energy-efficient policies would then lead to increased exports of energy related technologies, and, as a result, an increase in national competitiveness. This may be particularly important for developing and emerging economies.

Energy efficiency policies on a state level are designed to incentivize for innovations in the energy sector. State regulation in the energy sector is seen as necessary but needs to be flexible enough to facilitate innovations $[50,51]$. These policies have been deeply investigated for the European Union (EU) and the United States [52]. It has also been observed that the change in the energy systems in both the EU and the USA affected innovations. Similarly, a relationship between state energy policies and innovations has been observed in the United Kingdom's (UK) energy sector. Reforms aimed at liberalizing the UK electricity market had been causing a decrease in innovations until the state implemented specific policies reversing the situation [53].

At a regional level, there are typically two sets of policies. The first set is focused on the sustainability of a regional energy system. This is provided through, for example, an increasing share of renewable energy [54], or creating energy networks [55]. The literature supports that such goals require management of a regional energy system, based on careful monitoring, data collection and analysis [56], and delivering needed services [57].

The second set of policies are focused on developing an energy efficient regional economic system based on new technologies $[58,59]$. Here the idea is to use energy efficiency indicators to analyze and optimize energy consumption. Researchers point out the need to create a network among regional stakeholders [60], including but not limited to trade unions [61], households [40], and municipal service providers [62]. They also discuss promoting energy-saving technologies at a regional level, supporting standardization and cost saving, sharing information about energy-efficient behavior, and initiating technology driven structural changes in a regional economy. All of these regional policy examples connect energy efficiency and innovation.

The literature on the relationship between energy efficiency processes and innovations shows a lack of studies on a country and regional level for developing and emerging economies. While there is some research of the phenomenon for developed economies it is difficult to project these results on developing countries $[63,64]$. This is because developing 
countries generally recognize the importance of energy-efficient and environmentally safe technologies but can be too busy with more survival-oriented strategies. This is especially true for countries with no shortage of energy resources and relatively low energy prices. Some findings even confirm a negative relationship between energy efficiency policies and economic growth within developing countries [65]. These contradictory findings, as well as a lack of research on the relationship between energy efficiency and innovation in developing and emerging economies, provide additional evidence for the need for this study.

Thus, in addition to the discussed above traditional approach of innovations influencing energy efficiency at regional and national economies level, we confirm a reverse relationship and positive affect of energy efficiency on further developments of innovations. This contributes to understanding of sustainability of economic development as a spiral relationship within energy efficiency-innovation categories.

\section{Energy Efficiency and Innovation in the Russian Economy}

Because energy security is critical for national economies, countries focus on energy efficiency and tend to develop policies aimed at reducing dependence on a specific energy supply $[66,67]$. As seen in Figure 1, the nature of the dependence on energy supplies from country to country is rather diverse. The value on the vertical axis of the diagram in Figure 1 indicates the coverage of each nation's domestic needs through imports. Negative values indicate that a country has a "safety margin" of their own energy resources. In 2013, in Japan, South Korea, Turkey and the EU countries, energy dependence on imported energy sources was higher than $50 \%$ of the total energy need. A slightly smaller ratio is indicated for India, the USA, Argentina, China and Brazil. Russia is among the countries that have sufficient resources for its own needs, and also exports energy resources [68].

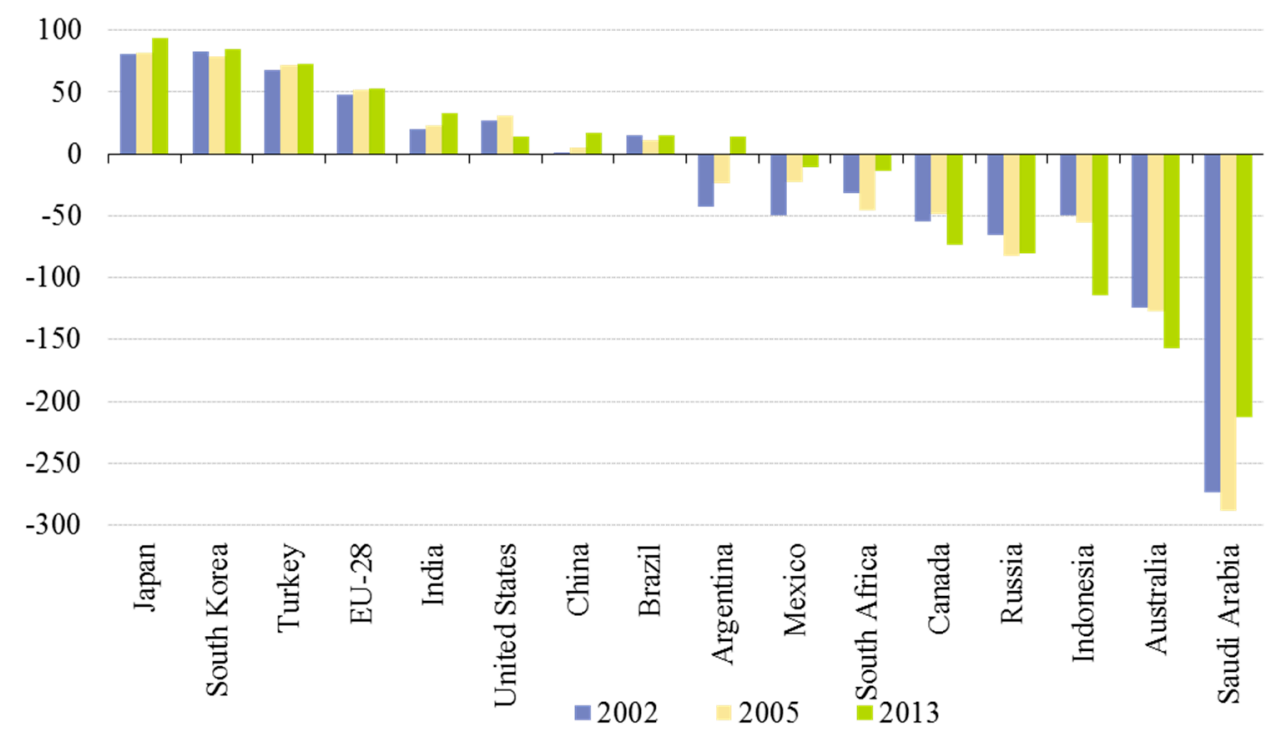

Figure 1. Dependence on energy supply in 2002, 2005 and 2013 (by country); in \%.

Obviously, the lower the level of energy dependence, the less concern a country has about its national energy security. Energy exporters are apparently the least concerned with energy security [69]. This can have both a positive and negative impact. Energy security is commonly seen as one of the driving forces behind technological innovations in the energy sector. For countries that are energy resource exporters this force is definitely not a driving one. Thus, it is up to government policy to support energy efficiency trends, as was done in Russia [70]. Russia has realized that the share of energy prices in their industrial products continues to be $2-3$ times higher than in well developed economies, which negatively impacts the competitiveness of Russian products in international markets (Figure 2). The level of energy intensity in Gross Domestic Product (GDP) is affected by multiple factors, 
including, product technology, energy resource prices, and also the costs, associated with delivery, distribution and consumption of energy resources as well as state/regional and municipal energy efficiency policies [71,72].

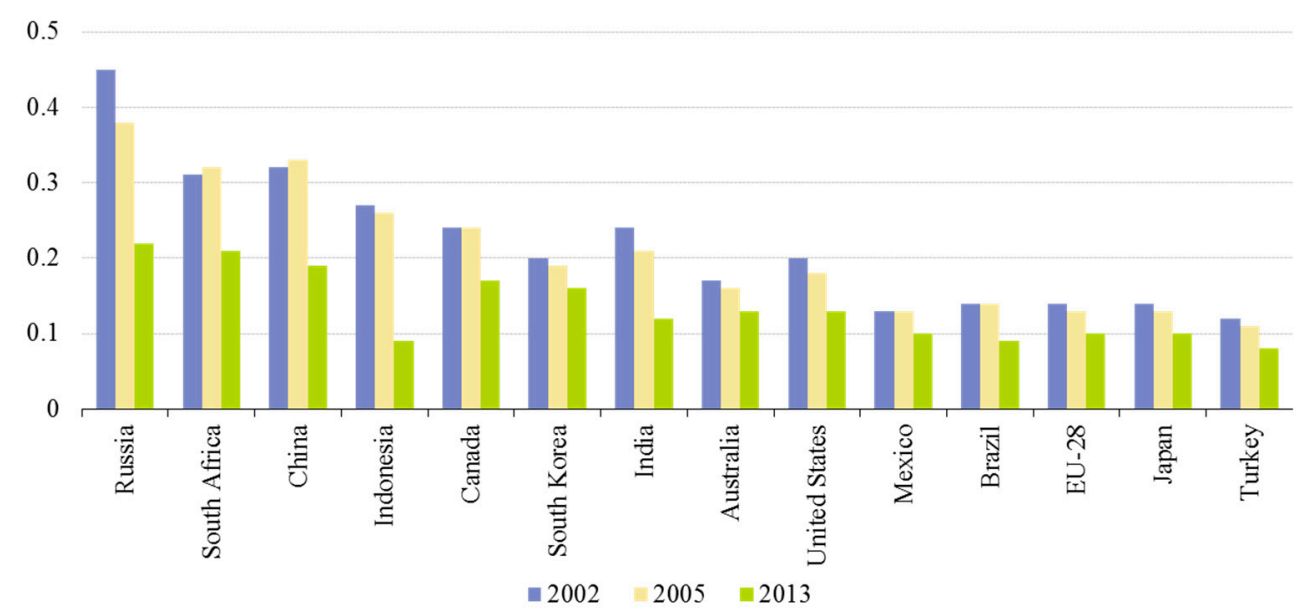

Figure 2. Energy intensity in 2002, 2005 and 2012 (by country), in tons of oil equivalent (toe) per 1000 USD of GDP. Source: the indicator is calculated by authors as ratio between the gross inland consumption of energy and GDP based on the data from Eurostat (2017) and The Organization for Economic Cooperation and Development (OECD) (2017). [73,74]

\section{Energy Intensity}

Given that services represent a larger portion of the economy in well developed countries, the energy intensity of their GDP is lower than for countries like Russia, where the proportion of heavy machinery industries, metallurgy and other manufacturing industries is significant [75-77]. The strategic focus of the Group of Twenty (G-20) countries on energy security and efficiency resulted in a substantial reduction of energy intensity in the GDP of those countries, as well as a reduction of gross domestic consumption per fuel type per capita and a reduction in total energy consumption $[63,78,79]$. In spite of similar actions in Russia [80], Russia has retained its position as the most energy-intensive economy among the G-20 countries.

To reduce the energy intensity in their GDP, governments motivate businesses to use new equipment and new technologies [35,81]. They develop taxation policies and grants, supporting the focus of research and development on energy saving and energy efficient technologies [82].

Figure 3 shows the Research and Development (R\&D) spending on energy and environment protection in 2014. According to the data from the Organization for Economic Development (The OECD, 2015) [83], the average R\&D spending of member states in the energy sector was about $4.5 \%$ of total governmental spending on $R \& D$, with almost $1.7 \%$ spent on environment protection.

The countries that have achieved the best results in energy intensity reduction invested heavily in R\&D. This is true for their energy sectors as well. Russia's R\&D expenditures on energy efficient technologies are far behind the well-developed countries. While the United States (1.8\%) and Russia (2\%) spend comparable proportions of their R\&D spending on energy efficient technologies, when compared in dollar terms, the 337 million USD spent in Russia varies considerably from the 2952 million USD spent in the United States. Japan is an example of even higher amounts streamed into R\&D in their energy sector, reaching $12.1 \%$ (around 4800 million USD). 


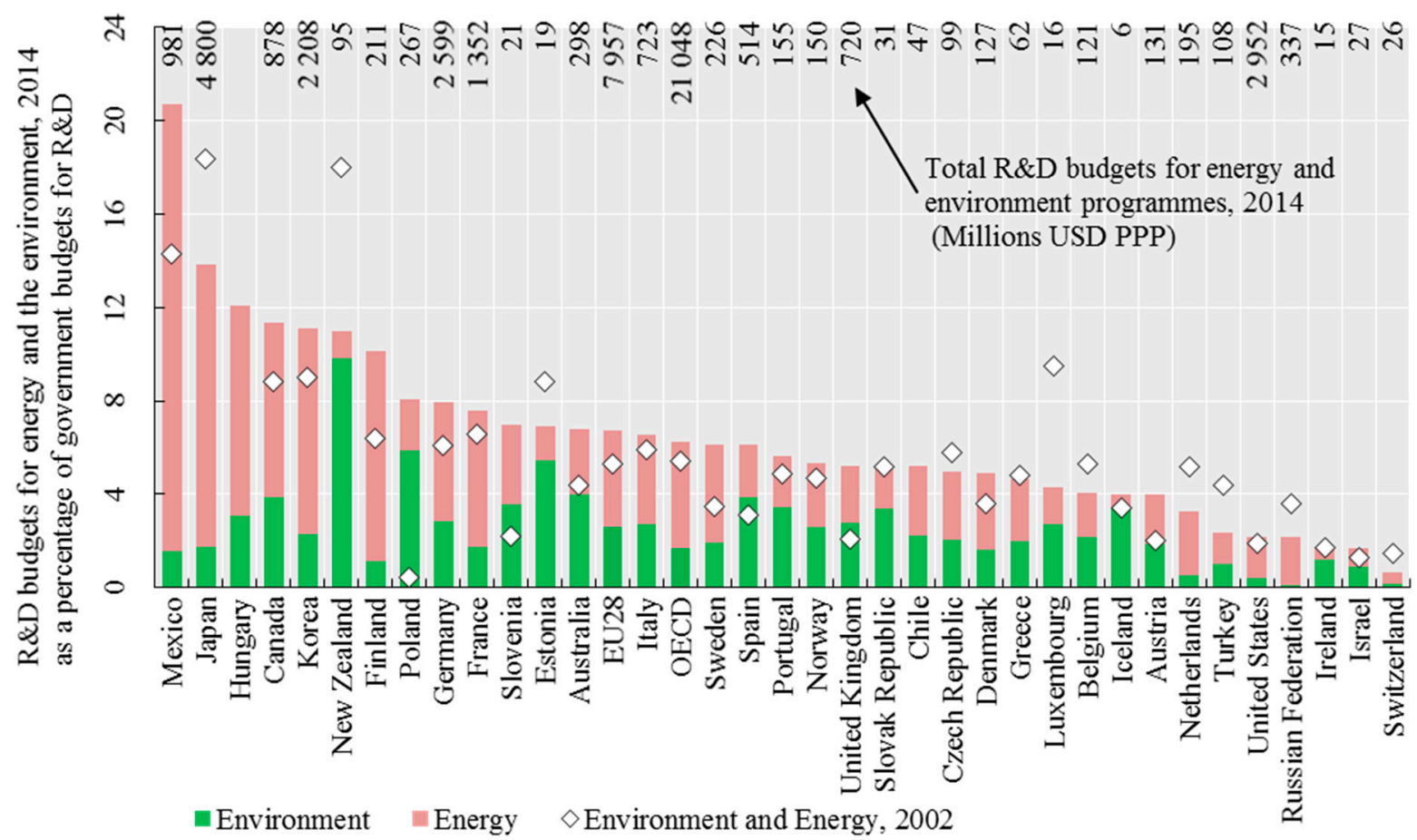

Figure 3. R\&D budgets for energy and environment protection in all R\&D expenditures in 2014 (by country); in \% of total R\&D expenditures, and also in million USD in purchasing power parity (PPP). Source: The Organization for Economic Cooperation and Development (OECD) (2017) [74].

Energy security and energy efficiency goals at a national level are determined by the strategic interest of a country [84]. Thus, countries adopt various protectionist policies to support R\&D in the energy sector aiming to achieve their goals $[85,86]$. They typically come up with criteria and rank them according to their importance. Such policies set a powerful impetus for innovative modernization of national economies [87], and as a result, support global competitiveness.

\section{Innovation in the Energy Sector in Russia}

Russia has been successful in developing innovation strategies in the energy sector $[88,89]$. Additionally, the literature [90-92] explains the problems Russia faces with their traditional short-term approach and somewhat simplified view of energy conservation and energy efficiency which has been prevailing over the years. A long-term focus has not been developed. Scholarly analysis of the situation and investigation of the relationship between energy efficiency and innovation in Russia is an area that has received limited attention [92].

Similar to other countries, including the United States, where regional economies are growing unevenly because of their internal policies, Russia's regions have also been focusing on economic growth. Decentralization of Russia's economy calls for energy efficiency research focused on regional investments [93-96]. The rationale behind regionally focused energy efficiency policies is connected with the efficient use of fuel and energy resources in enhancing the competitiveness of regional industries [30]. This helps to reduce the cost of production and disruption of energy market instability. In addition, it leads to company internal innovations and improved competitiveness [97]. While it is well researched at the level of a company or a state $[98,99]$ it has not yet been investigated at a regional economy level.

\section{Measures and Methods.}

Our goal was to test the relationship between energy efficiency and the level of industrial innovation across regions of Russia. In order to test that relationship, we utilized 
2014 data from 83 regions of the Russian Federation. Our measures consisted of two groups of indicators that reflect energy efficiency levels and regional innovation levels.

\subsection{Energy Efficiency Indicators}

The energy efficiency indicators were calculated based on a ranking of the energy efficiency of companies by regions. These data were acquired through an independent media source, International Services Group Interfax [100]. Energy efficiency is calculated by dividing the energy cost used to produce a product or service by the total costs of its production, including the costs of environmental impact. The total environmental impact is composed of six elements, including the amount of water used, the discharge of contaminated sewage, the emission of pollution into the atmosphere by polluting technologies and cars, the waste (of the 1-4 levels of danger) and the use of land [100].

We calculated the average value of the energy efficiency of the entire sample in order to use as a base level for comparisons. We use that average as $100 \%$ in order to calculate regional energy efficiency values. Regional energy efficiency was calculated as an average of the data reported by industrial enterprises in each region. Each value for regional energy efficiency is then represented as a percentage of the average value of the entire sample in order to arrive at a ranking. In other words, if the energy efficiency in a region is twice as high as the sample average, it was recorded at a $200 \%$ level. Similarly, if energy efficiency in a region is half of the entire sample/country average, it was recorded at the level of $50 \%$. This approach enabled us to compare indicators for regions with different socio-economic situations.

We used the Interfax [100] ranking for assessing regional energy efficiency instead of traditional indicators, such as energy intensity of Gross Regional Product (GRP), or energy intensity of labor, etc., for two reasons. First, the Interfax ranking is based on industrial enterprise data and does not include the other sectors of each regional economy that actually have little to do with introducing industrial innovations. Secondly, the "Interfax" ranking reflects changes in efficiency of production, while, for example, the energy intensity of GRP depends on the existing composition of the region's industries [101,102].

\subsection{Innovation Indicators}

For our second group of indicators we utilized open statistics collected and published by the Russian Federal Services of Statistics. These indicators include regional innovation statistics at all three main stages of an innovation life cycle. Those stages include R\&D, introduction of innovation and innovation commercialization. For the R\&D stage, a share of regional expenditures on R\&D in the Gross Regional Product (GRP) is used as the first indicator (Y1). Regional R\&Ds include all the research and development costs, including equipment costs, salaries, etc.

The share of enterprises/companies that undertook technological and organizational innovations in the reporting year of the total number of organizations surveyed was our second indicator representing the introduction of innovation stage (Y2). In this research, we used the open data of the Russian Federal State Agency Russian Export Center [98] on high-tech exports (it does not include raw materials and energy) to calculate the following:

$$
Y 2=\frac{K i}{K o} * 100 \%
$$

where Ki-number of organizations with innovative activities (marketing, technological, organizational innovations and others listed in the OECD guidelines [103,104]; Ko-the number of companies reported on survey to the Russian Federal Services of Statistics.

Finally, at the commercialization stage, the share of high-tech and knowledge intensive industries in GRP was our third indicator (Y3).

$$
Y 3=\frac{G V A}{G R P} * 100 \%
$$


where GVA-A gross value-added product of all high-tech activities in a selected region (in current prices), and GRP is a gross regional product of that region.

We used the data of all three phases of innovation activities: research and development, implementation and commercialization. The reason for the detailed analysis here is to show the relationship between energy efficiency and all these abovementioned phases as an addition to some authors that underline the existence of a connection between energy efficiency and the final result of the innovation process, as it was done by Galeotti et al. [105] for ecological innovations, Irandoust [106] for technology-based innovations and Caramizaru et al. [107] for social innovations. The data for innovation and energy efficiency of regional economies in 2014 for two major Federal districts, Central and Volga region, are presented in Table 1 . These Federal districts are formally composed of a number of territorially large (some comparable in area to the areas of European countries) and economically independent regions with significant autonomy in adoption of economic policies, like Tatarstan, for example, which has its own internal Parliament and President. 
Table 1. Innovation and energy efficiency: initial 2014 data for Central and Volga-region Federal districts of Russian Federation.

\begin{tabular}{|c|c|c|c|c|c|}
\hline Federal Districts & Russian Regions & $\begin{array}{c}\text { Energy-Resource Efficiency } \\
\text { According to Interfax in } \\
\text { 2015, \% }\end{array}$ & $\begin{array}{l}\text { Share of Internal Costs for } \\
\text { Research and Development } \\
\text { in GRP, \% }\end{array}$ & $\begin{array}{c}\text { Innovative Activity of Organizations, } \\
\% \text { of Total Number of Organizations } \\
\text { Surveyed }\end{array}$ & $\begin{array}{c}\text { Share of High-Tech and } \\
\text { High-Tech Industries in } \\
\text { GRP, \% }\end{array}$ \\
\hline \multirow{15}{*}{ Central Federal district } & Belgorod Region & 111.9 & 0.29 & 12.7 & 10.4 \\
\hline & Vladimir Region & 121.2 & 1.11 & 11.2 & 27.2 \\
\hline & Voronezh Region & 107.2 & 0.90 & 11.0 & 18.3 \\
\hline & Ivanovo Region & 121.0 & 0.43 & 4.4 & 22.1 \\
\hline & Kaluga Region & 106.6 & 3.17 & 10.9 & 35.8 \\
\hline & Kursk Region & 111.3 & 1.17 & 7.3 & 18.3 \\
\hline & Lipetsk Region & 105.8 & 0.07 & 20.0 & 11.6 \\
\hline & Moscow Region & 123.3 & 3.84 & 8.0 & 23.7 \\
\hline & Orel Region & 116.8 & 0.22 & 9.6 & 18.8 \\
\hline & Ryazan Region & 112.1 & 0.50 & 12.7 & 22.1 \\
\hline & Smolensk Region & 93.1 & 0.45 & 7.3 & 21.5 \\
\hline & Tambov Region & 94.9 & 0.83 & 9.6 & 15.9 \\
\hline & Tver Region & 102.7 & 1.35 & 7.9 & 21.0 \\
\hline & Tula Region & 122.2 & 0.76 & 12.9 & 36.7 \\
\hline & Moscow & 112.6 & 2.33 & 19.7 & 19.2 \\
\hline \multirow{14}{*}{$\begin{array}{c}\text { Volga-region Federal } \\
\text { District }\end{array}$} & Republic of Bashkortostan & 101.0 & 0.66 & 9.1 & 20.4 \\
\hline & Republic of Mari El & 108.9 & 0.10 & 8.3 & 24.2 \\
\hline & Republic of Mordovia & 103.4 & 0.57 & 16.6 & 21.1 \\
\hline & Republic of Tatarstan & 116.7 & 0.73 & 20.5 & 19.2 \\
\hline & Udmurtian Republic & 111.7 & 0.23 & 10.2 & 23.8 \\
\hline & Chechen Republic & 111.7 & 0.65 & 24.0 & 28.3 \\
\hline & Perm Territory & 95.1 & 1.21 & 10.5 & 29.1 \\
\hline & Kirov Region & 100.7 & 0.54 & 9.8 & 28.4 \\
\hline & Nizhny Novgorod Region & 132.4 & 5.75 & 13.5 & 29.3 \\
\hline & Orenburg Region & 93.3 & 0.08 & 10.8 & 11.8 \\
\hline & Penza Region & 112.4 & 1.18 & 14.7 & 23.0 \\
\hline & Samara Region & 105.3 & 1.27 & 5.0 & 26.2 \\
\hline & Saratov Region & 95.5 & 0.59 & 6.3 & 23.0 \\
\hline & Ulyanovsk Region & 116.0 & 3.15 & 5.2 & 30.0 \\
\hline
\end{tabular}


Correlation analysis was used to examine possible relationships between the two groups of indicators. Correlation analysis is widely used in econometric research for innovations and energy efficiency [109-111]. The limitation of this method is the inability to confirm the causality of relationships of variables as it is done in Garnger causality tests (as it is done in Narayan and Smyth [112] for electricity consumption), and also inability to reach the quality of fixed effect model or random effect model [113]. Although important limitations exist, they are not diminishing the value of finding out the relationship between energy efficiency, their direct and reverse influence over each other which is our goal in the current paper. We would use Garnger test and fixed and random effect models in our other works to better understand the depth and specifics of these relationship.

Figure 4 shows the results for energy efficiency $(X)$ and innovation related indicators $(\mathrm{Y} 1, \mathrm{Y} 2$, and $\mathrm{Y} 3)$.

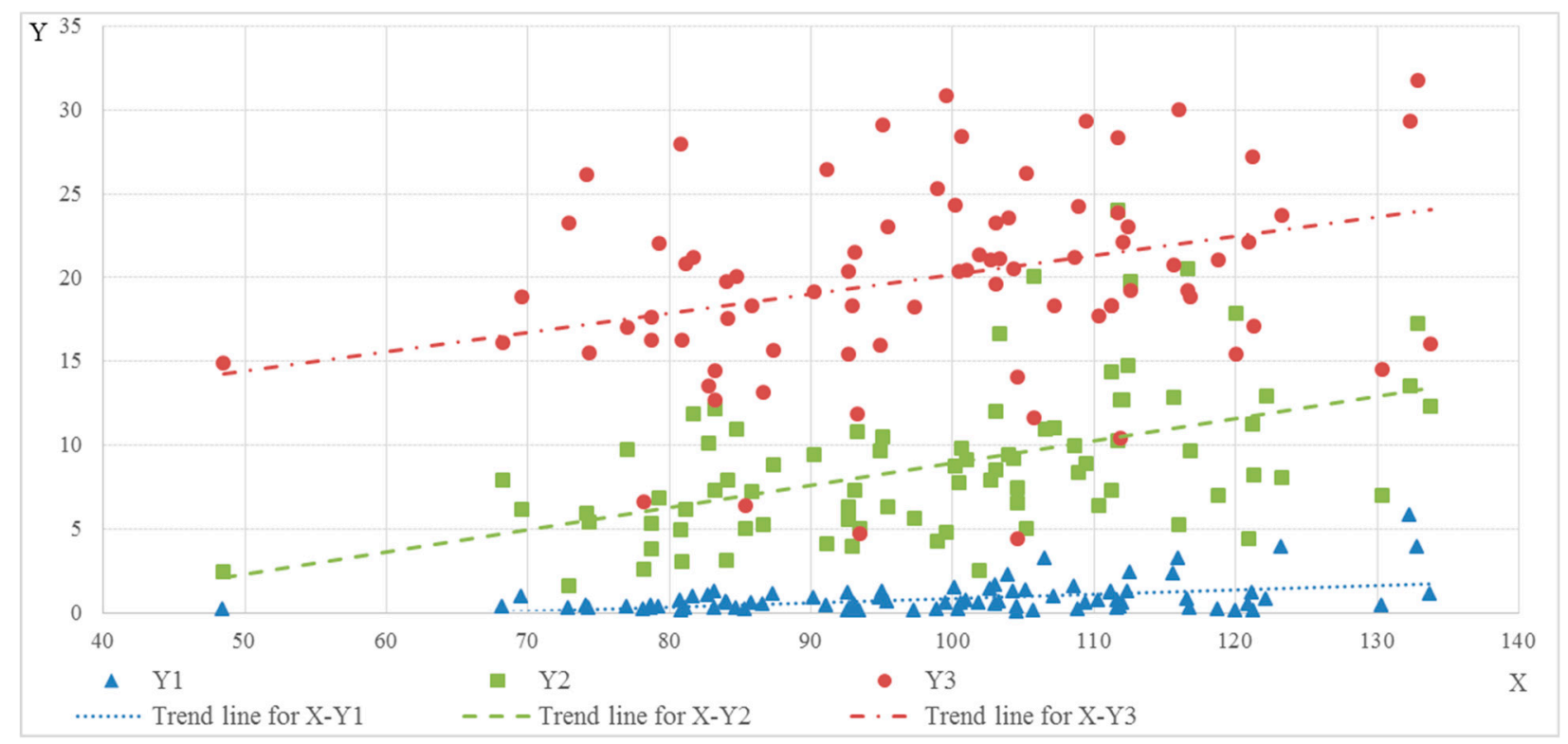

Figure 4. Correlation for energy efficiency and innovation X-energy-resource efficiency according to Interfax, \%; Y1-share of domestic expenditures on R\&D in GRP, \%; Y2-innovative activity of organizations,\%; Y3-the share of high-tech and knowledge-intensive industries in GRP, \%. Source: Interfax (2017) [100].

Based on the analysis of the above graph, we expect a linear relationship between indicators. Next, least squares analysis was used to estimate regression parameters. The resulting multiple regression equations reflecting the general trend in the behavior of the variables are presented in Table 2.

Table 2. Regression equations and their main indicators.

\begin{tabular}{cccc}
\hline Regression Equation & $\begin{array}{c}\text { Correlation } \\
\text { Coefficient }\end{array}$ & $\begin{array}{c}\text { Significance of Correlation } \\
\text { Coefficient, } \boldsymbol{t} \text {-test; } \boldsymbol{\alpha}=\mathbf{0 . 0 5}\end{array}$ & $\begin{array}{c}\text { Coefficient of } \\
\text { Elasticity, E }\end{array}$ \\
\hline $\mathrm{Y} 1=0.03 \mathrm{X}-1.7$ & 0.438 & Significant & 3.08 \\
\hline $\mathrm{Y} 2=0.13 \mathrm{X}-4.28$ & 0.502 & Significant & 1.48 \\
\hline $\mathrm{Y} 3=0.11 \mathrm{X}+8.66$ & 0.309 & Significant & 0.57 \\
\hline
\end{tabular}

The obtained correlation coefficients between $\mathrm{X}$ and $\mathrm{Y} 1, \mathrm{Y} 2$, and $\mathrm{Y} 3$ are, respectively, $0.438,0.502$ and 0.309 , which, according to the Chaddock scale, denotes the average relationship between indicators. According to the Student's t-criterion at $\alpha=0.05$ significance level, the relationship between the effective traits and the factor trait $X$ is significant, and the corresponding coefficient is statistically significant. Because heteroscedasticity of random errors leads to incorrect estimates in least square analysis, a heteroscedasticity test was 
performed. Using the Spearman [114] rank correlation test, the hypothesis of the absence of heteroscedasticity for each of the regression equations was supported.

As a result of the analysis, the average tightness of the relationship between energy efficiency and innovation performance was determined. The results indicate support for the general hypothesis that there is a relationship between energy efficiency and innovativeness. This is in agreement with the literature based on Russian data [115], as well as similar empirical studies in other countries $[27,116]$. Notably, the absence of high tightness values in our measures can be interpreted in a number of ways. First, energysaving and energy efficiency policies are typically planned and implemented separately with no connection to policies supporting regional innovations [117]. Second, energy saving and energy efficiency policies in Russia traditionally are focused primarily on residential housing services, state-owned companies, state educational institutions and, etc., paying less attention to regional private industrial enterprises [118]. Third, Russian regions use different policies for motivating regional enterprise efforts in innovation development [119]. The obtained results confirm the relationship between energy efficiency and innovative developments for Russian regions. As mentioned, correlation analysis has some limitations, but they are not impacting our current objective which is to establish a relationship between energy efficiency and innovation. The traditional approach is in focusing on the effect of innovation on energy efficiency, while we are investigating the reverse relationship. Correlation analysis is used to confirm statistically that the reverse relationship exists.

\section{The Role of Energy Efficiency in Socio-Economic Development of Russian Regions}

We also sought to test whether energy efficiency contributes positively to the socioeconomic development of a region. In order to test that we used increased export and Foreign Direct Investments (FDI) as indicators of a higher level of socio-economic development of a region $[120,121]$.

A regional export indicator (export commodity structure) was used as a dependent variable. In this research, we used the open access data of the Russian State Agency "Russian Export Center" on the high-tech exports (it does not include raw materials and energy).

Energy efficiency was used as the independent variable based again on the ranking of energy-resource efficiency by the Interfax news agency.

We selected portions of the data set of 83 Russian regions to create two groups. The first group is composed of the 10 regions with the highest energy efficiency (energy efficiency index 1.2 and higher). The second group is composed of the 10 regions with the lowest energy efficiency (index of 0.8 or lower). This coefficient is calculated as energy efficiency divided by the overall average for the data set. This measure is presented in Table 3.

We used ANOVA to detect the influence of energy efficiency on the dependent variable of export activity. In the analysis, the degree of influence for the factor of energy efficiency on regions within the sample was determined by comparing the variances of two groups: those with the presence of the factor (high energy efficient regions) and those without this factor (low energy efficient regions). The resulting F-values (Table 4) indicate a significant effect of energy efficiency on regional exports (with energy-resource exports being excluded from the sample). Additionally, the mutual influence between energy efficiency and innovation development has a secondary effect on socio-economic development of Russian regions, including, their exporting activities. 
Table 3. Baseline data for 2014 for regions with high and low energy efficiency.

\begin{tabular}{|c|c|c|}
\hline & $\begin{array}{l}\text { Energy-Resource Efficiency According } \\
\text { to Interfax [46] in } 2015, \%\end{array}$ & $\begin{array}{l}\text { Upper Redistribution of Non-Primary } \\
\text { Non-Energy Exports, Billion USD }\end{array}$ \\
\hline \multicolumn{3}{|c|}{ Regions with Low Energy Efficiency } \\
\hline Republic of Kalmykia & 48.5 & 0 \\
\hline Republic of Adygeya & 68.3 & 0.01 \\
\hline Primorye Territory & 69.6 & 0.05 \\
\hline Chechen Republic & 72.9 & 0 \\
\hline Arkhangelsk Region & 74.2 & 0.21 \\
\hline Amur Region & 74.4 & 0 \\
\hline Khabarovsk Territory & 77.1 & 0.03 \\
\hline Sakhalin Region & 78.2 & 0.16 \\
\hline Jewish Autonomous Region & 78.8 & 0 \\
\hline Republic of North Ossetia-Alania & 78.8 & 0.01 \\
\hline \multicolumn{3}{|c|}{ Regions with High Energy Efficiency } \\
\hline Chukotka Autonomous Area & 120.1 & 0 \\
\hline Ivanovo Region & 121.0 & 0.11 \\
\hline Vladimir Region & 121.2 & 0.82 \\
\hline Kostroma Region & 121.3 & 0.12 \\
\hline Tula Region & 122.2 & 1.5 \\
\hline Moscow Region & 123.3 & 3.87 \\
\hline Republic of Sakha (Yakutia) & 130.4 & 0.32 \\
\hline Nizhny Novgorod Region & 132.4 & 1.13 \\
\hline St. Petersburg & 132.9 & 3.41 \\
\hline Tyumen Region & 133.8 & 0.25 \\
\hline
\end{tabular}

Sources: Federal State Statistic Service, Russian Federation, (2017) [108]; Interfax, (2017) [100].

Table 4. Results of ANOVA analysis.

\begin{tabular}{|c|c|c|c|c|c|c|c|c|c|c|}
\hline \multirow{2}{*}{ Dependent Variable } & \multicolumn{2}{|c|}{$\begin{array}{c}\text { Dispersion } \\
\text { between Groups }\end{array}$} & \multicolumn{3}{|c|}{$\begin{array}{l}\text { Dispersion within Groups } \\
\text { (Residual) }\end{array}$} & \multicolumn{2}{|c|}{ Total Variance } & \multirow[t]{2}{*}{$\mathbf{F}$} & \multirow[t]{2}{*}{$\mathbf{P}$} & \multirow[t]{2}{*}{ For } \\
\hline & SS & df & MS & SS & df & MS & & & & \\
\hline $\begin{array}{l}\text { The upper limit of non-primary } \\
\text { non-energy exports, billion USD }\end{array}$ & 6.11 & 1 & 6.11 & 17.75 & 18 & 0.98 & 23.86 & 6.20 & 0.022 & 4.41 \\
\hline
\end{tabular}

The reverse influence of energy efficiency on innovation in purpose of the increase of regional exports of high-tech industries could be described as following. High-tech enterprises establish higher standards and requirements for energy supply for high-tech industries, digital systems and precision production [122-124]. Given sharp international competition, such companies require the same energy efficiency level as foreign rivals [125,126]. Thus, regional policies could support innovation and exporting by stimulating energy efficiency in the region. However, energy efficiency supports exports of high-tech industries in limited conditions. First, it is true for economically well-developed regions with a significant share of industries producing high-tech goods. They would have strict requirements for energy infrastructure. Second, the impact of energy efficiency on high-tech exports is possible only if high-tech enterprises in the region already export their products and feel the competitive pressure of international markets. In such conditions, high-tech enterprises become directly interested in regional mechanisms supporting energy efficiency. In turn, for regional authorities, this opens up opportunities for improving their regional economy, and investing in development activities.

\section{Regional Policies Supporting Innovation in Energy Efficiency and Energy Saving}

The study resulted in several important findings: energy efficiency impacts innovation in the region; innovation affects energy efficiency. The upward spiral relationship between 
energy efficiency and innovation was found. Mutually impactful energy efficiency and innovation influence regional economic development and support the development of exports. Thus, there are the following insights for regional policies. First, regional policies could focus on innovative technologies requiring high quality and reliable sources of energy supply. Second, regions could introduce requirements for disclosing energy efficiency levels for every industry product item. Third, regions could support piloting cooperative projects introducing new technologies. Finally, regions could support innovation in the area of energy saving.

We developed a $3 \times 4$ matrix made of possible components that could be included in the above policies (Table 5). For the three rows, we used activities on a regional level, industry level and society in general. The columns include political, economic, social and technological level policy components. The matrix does not include region specific conditions and has to be adjusted by each region's administration accordingly. The energy efficiency/innovation matrix could be used as a tool for designing regional programs and strategies supporting energy saving and efficient technologies and industries, as well as innovations in the region.

Like many countries, Russia adopted the European Union's ban on the use of incandescent lights which fueled the introduction of LED lights, and helped in saving energy. Other examples of energy efficient policies include long-term agreements to reduce the consumption of fuel and energy resources and the introduction of a white certificate mechanism that supports the implementation of technological innovations in the energy sector; promoting the use of electric and hybrid vehicles; focus on environmental responsibility and energy efficiency standards, such as forest and maritime certifications, green house building standards, etc. Thus policies, could both stimulate energy efficiency and also led to innovations in housing, forestry and other business areas. All Russia's regions adopted such policies and share best practices. The comparative analysis of these policies' outputs in the energy efficiency and innovation both on country's and international level is our future focus. 
Table 5. The matrix of major directions in implementing energy efficiency innovations.

\begin{tabular}{|c|c|c|c|c|}
\hline & Political Factors & Economic Factors & Social Factors & Technological Factors \\
\hline Organizational Level & $\begin{array}{l}\text { Participating in the announced state } \\
\text { programs }\end{array}$ & $\begin{array}{l}\text { Commercialization of energy efficient } \\
\text { technologies and innovations } \\
\text { Monitoring of energy efficiency and } \\
\text { energy costs at corporate level } \\
\text { Implementing industry best practices }\end{array}$ & $\begin{array}{l}\text { Developing of a positive image of a } \\
\text { benchmarking company through } \\
\text { marketing/advertising campaigns } \\
\text { in media (including social media) }\end{array}$ & $\begin{array}{l}\text { Using the energy saving/efficiency } \\
\text { criteria for adopting designs and } \\
\text { innovative technologies }\end{array}$ \\
\hline $\begin{array}{c}\text { Regional Level (Regional } \\
\text { Powers) }\end{array}$ & $\begin{array}{l}\text { Announcing regional programs for } \\
\text { energy efficiency and innovative } \\
\text { development } \\
\text { Coordination regional companies }\end{array}$ & $\begin{array}{l}\text { Supporting the companies implementing } \\
\text { energy saving/efficient innovations } \\
\text { (regional tax policy, grants, etc.) }\end{array}$ & $\begin{array}{l}\text { Developing of a positive image of a } \\
\text { region through } \\
\text { marketing/advertising campaigns } \\
\text { in media (including social media) }\end{array}$ & $\begin{array}{c}\text { Promoting best practices in energy } \\
\text { saving/efficiency through regional } \\
\text { shows and exhibitions focused on } \\
\text { technology innovations }\end{array}$ \\
\hline $\begin{array}{l}\text { Industry Level (Federal } \\
\text { Ministries) }\end{array}$ & $\begin{array}{l}\text { Announcing industry programs for } \\
\text { energy efficient innovations } \\
\text { Coordination industry companies }\end{array}$ & $\begin{array}{l}\text { Organizing and sponsoring of industry } \\
\text { wide exhibitions; incentivizing sharing } \\
\text { best practices at industry level }\end{array}$ & $\begin{array}{l}\text { Developing of a positive image of } \\
\text { an industry as a whole through } \\
\text { marketing/advertising campaigns } \\
\text { in media (including social media) }\end{array}$ & $\begin{array}{l}\text { Promoting industry wide } \\
\text { knowledge transfer and } \\
\text { commercialization of best practices }\end{array}$ \\
\hline
\end{tabular}

The indicator is calculated as net imports divided by the sum of gross inland energy consumption plus bunkers. Sources: Eurostat (2017) [73]; International Energy Agency (2017) [127,128]. 


\section{Conclusions and Limitations}

The study supports the conclusion that energy efficiency impacts innovative development in regional economies. The revealed effect of the mutual influence of energy efficiency and innovation is significant and statistically stable. It supports regional economic development, including exporting.

The theoretical significance of these results is not limited only to the regional economy. It expands the understanding of the role of energy efficiency in the development of the competitiveness of national economies, specifically important for emerging and developing markets. Due to limited energy sources the role of energy efficiency in regional and national competitiveness would increase. Countries and regions could develop strategies supporting the rational use of energy resources, reducing industrial waste and reducing negative impact on the environment. Based on our findings of the mutual impact of energy efficiency and innovation, the above strategies could be assessed by both level of energy saving/efficiency and share of innovative products ready for commercialization. Thus, while started at the regional level of a particular country, this approach could provide a background for further research of energy efficiency and innovation in a cross-country setting, and also could lead to recommendations for national policy makers.

The limitations of this study (the data collected within one, although very large, country) are also opening some future opportunities for us in testing our findings on other countries. As we discussed the limitations of econometric methods that we used for the purpose of this research, we pointed out that other methods will be used for in depth research for the purpose of comparative analysis across regions. We believe that practitioners and policy makers, as mentioned above, would be able to use our approach to grow regional economies. We see the opportunity for future sustainability research based on our research. We consider the relationship between energy efficiency and innovation to be able to develop in a spiral process: "innovation-energy efficiencyinnovation-energy efficiency". The already confirmed strong influence of innovation on energy efficiency $[110,129,130]$ was enriched by our findings of an existence of a reverse relationship. Therefore, strategic actions, which support innovations would lead to a higher level of energy efficiency, which in turn could lead again to innovations at the regional level. This logic for sustainable development of regional economics could be used by emerging economies.

Author Contributions: Formal analysis, A.M. and I.N.; Funding acquisition, K.E.; Investigation, A.M. and K.E.; Methodology, A.M. and K.E.; Writing-original draft, I.N. and J.K. All authors contributed to all phases of this project. All authors have read and agreed to the published version of the manuscript.

Funding: The study was performed under a grant from the Russian Science Foundation (project No. 16-18-10227).

Institutional Review Board Statement: Not applicable.

Informed Consent Statement: Not applicable.

Data Availability Statement: Publicly available datasets were analyzed in this study.

Acknowledgments: The study was performed under a grant from the Russian Science Foundation (project No.16-18-10227).

Conflicts of Interest: The authors declare no conflict of interest.

\section{References}

1. Lélé, S.M. Sustainable development: A critical review. World Dev. 1991, 19, 607-621. [CrossRef]

2. Yergin, D. Ensuring Energy Security. Foreign Aff. 2006, 85, 69. [CrossRef]

3. Herring, H. Energy efficiency-A critical view. Energy 2006, 31, 10-20. [CrossRef]

4. Verbruggen, A.; Fischedick, M.; Moomaw, W.; Weir, T.; Nadaï, A.; Nilsson, L.J.; Nyboer, J.; Sathaye, J. Renewable energy costs, potentials, barriers: Conceptual issues. Energy Policy 2010, 38, 850-861. [CrossRef]

5. Wunder, S.; Engel, S.; Pagiola, S. Taking stock: A comparative analysis of payments for environmental services programs in developed and developing countries. Ecol. Econ. 2008, 65, 834-852. [CrossRef] 
6. Hang, C.-C.; Chen, J.; Subramian, A.M. Developing Disruptive Products for Emerging Economies: Lessons from Asian Cases. Res. Manag. 2010, 53, 21-26. [CrossRef]

7. Hepbasli, A.; Ozalp, N. Development of energy efficiency and management implementation in the Turkish industrial sector. Energy Convers. Manag. 2003, 44, 231-249. [CrossRef]

8. Morrow, W.R., III; Hasanbeigi, A.; Sathaye, J.; Xu, T. Assessment of energy efficiency improvement and CO2 emission reduction potentials in India's cement and iron \& steel industries. J. Clean. Prod. 2014, 65, 131-141.

9. Sardianou, E. Barriers to industrial energy efficiency investments in Greece. J. Clean. Prod. 2008, 16, 1416-1423. [CrossRef]

10. Al-Mansour, F.; Merse, S.; Tomsic, M. Comparison of energy efficiency strategies in the industrial sector of Slovenia. Energy 2003, 28, 421-440. [CrossRef]

11. Fromme, J. Energy conservation in the Russian manufacturing industry. Potentials and obstacles. Energy Policy 1996, 24, 245-252. [CrossRef]

12. Shrivastava, P. Environmental technologies and competitive advantage. Strat. Manag. J. 1995, 16, 183-200. [CrossRef]

13. Ünler, A. Improvement of energy demand forecasts using swarm intelligence: The case of Turkey with projections to 2025 . Energy Policy 2008, 36, 1937-1944. [CrossRef]

14. Soytas, U.; Sari, R. Energy consumption, economic growth, and carbon emissions: Challenges faced by an EU candidate member. Ecol. Econ. 2009, 68, 1667-1675. [CrossRef]

15. Deng, P. Outward investment by Chinese MNCs: Motivations and implications. Bus. Horiz. 2004, 47, 8-16. [CrossRef]

16. Asheim, B.T.; Boschma, R.; Cooke, P. Constructing regional advantage: Platform policies based on related variety and differentiated knowledge bases. Reg. Stud. 2011, 45, 893-904. [CrossRef]

17. Menanteau, P.; Finon, D.; Lamy, M.-L. Prices versus quantities: Choosing policies for promoting the development of renewable energy. Energy Policy 2003, 31, 799-812. [CrossRef]

18. Camagni, R.; Capello, R. Regional competitiveness and territorial capital: A conceptual approach and empirical evidence from the European Union. Reg. Stud. 2013, 47, 1383-1402. [CrossRef]

19. Kaveshnikov, N. The issue of energy security in relations between Russia and the European Union. Eur. Secur. 2010, 19, 585-605. [CrossRef]

20. Correlje, A.; Van der Linde, C. Energy supply security and geopolitics: A European perspective. Energy Policy 2006, 34, 532-543. [CrossRef]

21. Lukman, R.K.; Glavič, P.; Carpenter, A.; Virtič, P. Sustainable consumption and production-Research, experience, and development-The Europe we want. J. Clean. Prod. 2016, 138, 139-147. [CrossRef]

22. Bornschlegl, M.; Bregulla, M.; Franke, J. Methods-Energy Measurement-An approach for sustainable energy planning of manufacturing technologies. J. Clean. Prod. 2016, 135, 644-656. [CrossRef]

23. Li, M.J.; Tao, W.Q. Review of methodologies and polices for evaluation of energy efficiency in high energy-consuming industry. Appl. Energy 2017, 187, 203-215. [CrossRef]

24. Bhattacharya, M.; Paramati, S.R.; Ozturk, I.; Bhattacharya, S. The effect of renewable energy consumption on economic growth: Evidence from top 38 countries. Appl. Energy 2016, 162, 733-741. [CrossRef]

25. Qureshi, M.I.; Rasli, A.M.; Zaman, K. Energy crisis, greenhouse gas emissions and sectoral growth reforms: Repairing the fabricated mosaic. J. Clean. Prod. 2016, 112, 3657-3666. [CrossRef]

26. Schandl, H.; Hatfield-Dodds, S.; Wiedmann, T.; Geschke, A.; Cai, Y.; West, J.; Newth, D.; Baynes, T.; Lenzen, M.; Owen, A. Decoupling global environmental pressure and economic growth: Scenarios for energy use, materials use and carbon emissions. J. Clean. Prod. 2016, 132, 45-56. [CrossRef]

27. Popp, D.; Newell, R.G.; Jaffe, A.B. Energy, the environment, and technological change. Handb. Econ. Innov. 2010,2 , 873-937.

28. Bunse, K.; Vodicka, M.; Schönsleben, P.; Brülhart, M.; Ernst, F.O. Integrating energy efficiency performance in production management-gap analysis between industrial needs and scientific literature. J. Clean. Prod. 2011, 19, 667-679. [CrossRef]

29. Boons, F.; Montalvo, C.; Quist, J.; Wagner, M. Sustainable innovation, business models and economic performance: An overview. J. Clean. Prod. 2013, 45, 1-8. [CrossRef]

30. Bobylev, S.; Kudryavtseva, O.; Yakovleva, Y. Regional Priorities of Green Economy. Econ. Reg. 2015, 2, $148-159$.

31. Costantini, V.; Crespi, F.; Palma, A. Characterizing the policy mix and its impact on eco-innovation: A patent analysis of energy-efficient technologies. Res. Policy 2017, 46, 799-819. [CrossRef]

32. Patterson, M.G. What is energy efficiency? Concepts, indicators and methodological issues. Energy Policy 1996, 24, 377-390. [CrossRef]

33. Jaffe, A.B.; Stavins, R.N. The energy-efficiency gap What does it mean? Energy Policy 1994, 22, 804-810. [CrossRef]

34. Popp, D. Induced Innovation and Energy Prices. Am. Econ. Rev. 2002, 92, 160-180. [CrossRef]

35. Newell, R.G.; Jaffe, A.B.; Stavins, R.N. The induced innovation hypothesis and energy-saving technological change. Q. J. Econ. 1999, 114, 941-975. [CrossRef]

36. Valderrama, C.; Granados, R.; Cortina, J.L.; Gasol, C.M.; Guillem, M.; Josa, A. Implementation of best available techniques in cement manufacturing: A life-cycle assessment study. J. Clean. Prod. 2012, 25, 60-67. [CrossRef]

37. Barreto, L.; Kemp, R. Inclusion of technology diffusion in energy-systems models: Some gaps and needs. J. Clean. Prod. 2008, 16, S95-S101. [CrossRef]

38. Popp, D.C. The effect of new technology on energy consumption. Resour. Energy Econ. 2001, 23, 215-239. [CrossRef] 
39. Cuerva, M.C.; Triguero-Cano, Á.; Córcoles, D. Drivers of green and non-green innovation: Empirical evidence in Low-Tech SMEs. J. Clean. Prod. 2014, 68, 104-113. [CrossRef]

40. Girod, B.; Stucki, T.; Woerter, M. How do policies for efficient energy use in the household sector induce energy-efficiency innovation? An evaluation of European countries. Energy Policy 2017, 103, 223-237. [CrossRef]

41. Brutschin, E.; Fleig, A. Innovation in the energy sector-The role of fossil fuels and developing economies. Energy Policy 2016, 97, 27-38. [CrossRef]

42. Urpelainen, J. Export orientation and domestic electricity generation: Effects on energy efficiency innovation in select sectors. Energy Policy 2011, 39, 5638-5646. [CrossRef]

43. Wan, J.; Baylis, K.; Mulder, P. Trade-facilitated technology spillovers in energy productivity convergence processes across EU countries. Energy Econ. 2015, 48, 253-264. [CrossRef]

44. Yang, C.; Liu, S. Spatial correlation analysis of low-carbon innovation: A case study of manufacturing patents in China. J. Clean. Prod. 2020, 273, 122893. [CrossRef]

45. Cao, B.; Wang, S. Opening up, international trade, and green technology progress. J. Clean. Prod. 2017, 142, 1002-1012. [CrossRef]

46. Ornetzeder, M.; Rohracher, H. User-led innovations and participation processes: Lessons from sustainable energy technologies. Energy Policy 2006, 34, 138-150. [CrossRef]

47. Lipp, J. Lessons for effective renewable electricity policy from Denmark, Germany and the United Kingdom. Energy Policy 2007, 35, 5481-5495. [CrossRef]

48. Costantini, V.; Crespi, F. Environmental regulation and the export dynamics of energy technologies. Ecol. Econ. 2008, 66, 447-460. [CrossRef]

49. Porter, M.E.; Van der Linde, C. Toward a new conception of the environment-competitiveness relationship. J. Econ. Perspect. 1995, 9, 97-118. [CrossRef]

50. Lanzi, E. Impacts of Innovation: Lessons from the Empirical Evidence. In Encyclopedia of Energy, Natural Resource, and Environmental Economics; Shogren, J., Ed.; Elsevier: Waltham, MA, USA, 2013; pp. 82-88.

51. Fri, R.W.; Savitz, M.L. Rethinking energy innovation and social science. Energy Res. Soc. Sci. 2014, 1, 183-187. [CrossRef]

52. De las Heras, B.P. Energy security policies in the European Union and the United States: Global challenges and common commitments in the transition towards a more sustainable energy model. Eur. Community Law Mag. 2014, $18,13-47$.

53. Jamasb, T.; Pollitt, M.G. Why and how to subsidise energy R + D: Lessons from the collapse and recovery of electricity innovation in the UK. Energy Policy 2015, 83, 197-205. [CrossRef]

54. Viholainen, J.; Luoranen, M.; Väisänen, S.; Niskanen, A.; Horttanainen, M.; Soukka, R. Regional level approach for increasing energy efficiency. Appl. Energy 2016, 163, 295-303. [CrossRef]

55. Hyytinen, K.; Toivonen, M. Future energy services: Empowering local communities and citizens. Foresight 2015, 17, 349-364. [CrossRef]

56. Luong, N.D. A critical review on Energy Efficiency and Conservation policies and programs in Vietnam. Renew. Sustain. Energy Rev. 2015, 52, 623-634. [CrossRef]

57. Thoyre, A. Energy efficiency as a resource in state portfolio standards: Lessons for more expansive policies. Energy Policy 2015, 86, 625-634. [CrossRef]

58. Liu, J.; Wang, L.; Qiu, M.; Zhu, J. Promotion Potentiality and Optimal Strategies Analysis of Provincial Energy Efficiency in China. Sustainability 2016, 8, 741. [CrossRef]

59. Ruiz-Fuensanta, M.J. The region matters: A comparative analysis of regional energy efficiency in Spain. Energy 2016, 101, 325-331. [CrossRef]

60. Bukarica, V.; Robić, S. Implementing energy efficiency policy in Croatia: Stakeholder interactions for closing the gap. Energy Policy 2013, 61, 414-422. [CrossRef]

61. Antonioli, D.; Mazzanti, M. Towards a green economy through innovations: The role of trade union involvement. Ecol. Econ. 2017, 131, 286-299. [CrossRef]

62. Yushchenko, A.; Patel, M.K. Cost-effectiveness of energy efficiency programs: How to better understand and improve from multiple stakeholder perspectives? Energy Policy 2017, 108, 538-550. [CrossRef]

63. Camioto, F.D.C.; Moralles, H.F.; Mariano, E.B.; Rebelatto, D.A.D.N. Energy efficiency analysis of G7 and BRICS considering total-factor structure. J. Clean. Prod. 2016, 122, 67-77. [CrossRef]

64. Parker, S.; Liddle, B. Economy-wide and manufacturing energy productivity transition paths and club convergence for OECD and non-OECD countries. Energy Econ. 2017, 62, 338-346. [CrossRef]

65. Cantore, N.; Calì, M.; Velde, D.W.T. Does energy efficiency improve technological change and economic growth in developing countries? Energy Policy 2016, 92, 279-285. [CrossRef]

66. Bompard, E.; Carpignano, A.; Erriquez, M.; Grosso, D.; Pession, M.; Profumo, F. National energy security assessment in a geopolitical perspective. Energy 2017, 130, 144-154. [CrossRef]

67. Sovacool, B.K.; Mukherjee, I.; Drupady, I.M.; D'Agostino, A.L. Evaluating energy security performance from 1990 to 2010 for eighteen countries. Energy 2011, 36, 5846-5853. [CrossRef]

68. Ji, Q.; Zhang, H.Y.; Fan, Y. Identification of global oil trade patterns: An empirical research based on complex network theory. Energy Convers. Manag. 2014, 85, 856-865. [CrossRef]

69. Narula, K.; Reddy, B.S. A SES (sustainable energy security) index for developing countries. Energy 2016, 94, 326-343. [CrossRef] 
70. Khrushcheva, O.; Maltby, T.F.R. The Future of EU-Russia Energy Relations in the Context of Decarbonisation. Geopolitics 2016, 21, 799-830. [CrossRef]

71. Dasgupta, S.; Van der Salm, F.; Roy, J. Designing PAT as a Climate Policy in India: Issues Learnt from EU-ETS. In Nature, Economy and Society; Springer: New Delhi, India, 2016; pp. 315-328.

72. Kuzminov, I.; Bereznoy, A.; Bakhtin, P. Global energy challenges and the national economy: Stress scenarios for Russia. Foresight 2017, 19, 174-197. [CrossRef]

73. Eurostat. The EU in the World, Energy. 2017. Available online: http://ec.europa.eu/eurostat/statistics-explained/index.php/ The_EU_in_the_world_-_energy (accessed on 12 December 2017).

74. The Organisation for Economic Cooperation and Development. OECD Data. 2017. Available online: https://data.oecd.org/ (accessed on 23 December 2017).

75. Geller, H.; Harrington, P.; Rosenfeld, A.H.; Tanishima, S.; Unander, F. Polices for increasing energy efficiency: Thirty years of experience in OECD countries. Energy Policy 2006, 34, 556-573. [CrossRef]

76. Kander, A.; Warde, P.; Henriques, S.T.; Nielsen, H.; Kulionis, V.; Hagen, S. International Trade and Energy Intensity During European Industrialization, 1870-1935. Ecol. Econ. 2017, 139, 33-44. [CrossRef]

77. Yu, S.; Zheng, S.; Ba, G.; Wei, Y.-M. Can China realise its energy-savings goal by adjusting its industrial structure? Econ. Syst. Res. 2016, 28, 273-293. [CrossRef]

78. Scaffardi, L.; Federico, V. The BRICS in the Spotlight: A Research Agenda. BRICS Law J. 2014, 1, 112.

79. Van de Graaf, T.; Westphal, K. The G8 and G20 as global steering committees for energy: Opportunities and constraints. Global Policy 2011, 2, 19-30. [CrossRef]

80. Melnik, A.; Mustafina, O. Investigation of the Reasons and Identification of Cyclic Recurrence in Intensification of the Resolution of the Problems of the Russian Economy's Energy Efficiency Enhancement. In Proceedings of the SGEM 2016, BK 2: Political Sciences, Law, Finance, Economics and Tourism, Albena, Bulgaria, 24-31 August 2016; Volume 5, pp. 409-416. [CrossRef]

81. De Groot, H.L.; Verhoef, E.T.; Nijkamp, P. Energy saving by firms: Decision-making, barriers and policies. Energy Econ. 2001, 23, 717-740. [CrossRef]

82. Kern, F.; Kivimaa, P.; Martiskainen, M. Policy packaging or policy patching? The development of complex energy efficiency policy mixes. Energy Res. Soc. Sci. 2017, 23, 11-25. [CrossRef]

83. The Organisation for Economic Cooperation and Development. OECD Science, Technology and Industry Scoreboard 2015: Innovation for growth and society. Available online: http:/ / dx.doi.org/10.1787/sti_scoreboard-2015-en (accessed on 23 December 2017).

84. Sovacool, B.K. Evaluating energy security in the Asia pacific: Towards a more comprehensive approach. Energy Policy 2011, 39, 7472-7479. [CrossRef]

85. Sohag, K.; Begum, R.A.; Abdullah, S.M.S.; Jaafar, M. Dynamics of energy use, technological innovation, economic growth and trade openness in Malaysia. Energy 2015, 90, 1497-1507. [CrossRef]

86. Wang, N.; Han, B. Effects of indigenous R\&D and foreign spillover on energy intensity in China. J. Renew. Sustain. Energy 2017, 9, 035901. [CrossRef]

87. Byrne, R.; de Coninck, H.C.; Sagar, A. Low-Carbon Innovation for Industrial Sectors in Developing Countries: Policy Brief. January 2014. Radboud University Working Papers. Available online: http://repository.ubn.ru.nl/bitstream/handle/2066/135 296/135296.pdf (accessed on 23 December 2017).

88. Kaznacheev, P.F.; Samoilova, R.V.; Kjurchiski, N.V. Improving Efficiency of the Oil and Gas Sector and Other Extractive Industries by Applying Methods of Artificial Intelligence. Econ. Policy 2016, 11, 188-197. [CrossRef]

89. Kapitonov, I.A.; Korolev, V.G.; Shadrin, A.A.; Shulus, A.A. The role of small and medium-sized innovative enterprises in the solution of the import substitution task in oil and gas-sector segment of the Russian fuel and energy complex. Int. J. Energy Econ. Policy 2017, 7, 137-145.

90. Li, F.; Butel, L.; Wang, P. Innovation policy configuration-A comparative study of Russia and China. Policy Stud. 2017, 38, 311-338. [CrossRef]

91. Suprun, E.V.; Stewart, R.A. Construction innovation diffusion in the Russian Federation:.Barriers, drivers and coping strategies. Constr. Innov. 2015, 15, 278-312. [CrossRef]

92. Ustyuzhantseva, O. Studies of inclusive innovation in sociotechnical systems: Case studies in Russia and India. Innov. Dev. 2017, 7, 83-100. [CrossRef]

93. Kuzemko, C. Ideas, Power and Change: Explaining EU-Russia Energy Relations. J. Eur. Public Policy 2013, 21, 58-75. [CrossRef]

94. Baev, I.A.; Solovyova, I.A.; Dzyuba, A.P. Regional reserves of energy efficiency. Econ. Reg. 2013, 3, 180-189. [CrossRef]

95. Danilov, N.; Silin, V.; Dobrodey, V.; Popov, V. Energy Problems of the Rational Use of the Economic Potential of the Region. In Energy Production and Management in the 21st Century; WIT Press: Ashurst, UK, 2014; Volume 190, pp. 419-423.

96. Melnik, A.N.; Dyrdonova, A.N. Energy Efficiency Improvement Ways in Industrial Clusters of the Region. Mediterr. J. Soc. Sci. 2015, 6, 141. [CrossRef]

97. Vishnevskiy, K.; Karasev, O.; Meissner, D. Integrated roadmaps and corporate foresight as tools of innovation management: The case of Russian companies. Technol. Forecast. Soc. Chang. 2015, 90, 433-443. [CrossRef]

98. Chen, M.; Sinha, A.; Hu, K.; Shah, M.I. Impact of technological innovation on energy efficiency in industry 4.0 era: Moderation of shadow economy in sustainable development. Technol. Forecast. Soc. Chang. 2021, 164, 120521. [CrossRef] 
99. Melnik, A.N.; Ermolaev, K.A. Conceptual framework for managing the energy saving and energy efficiency at industrial enterprises in the context of their innovative development. Econ. Anal. Theory Pract. 2019, 18, 22-39. [CrossRef]

100. Interfax. 2017. Available online: https:/ /interfax-era.ru/ (accessed on 12 December 2017).

101. Pakhomova, N.; Richter, K.; Zhigalov, V.; Malova, A. Management of Energy-Efficiency in the Context of New Climate Policy. Econ. Reg. 2017, 13, 183-195. [CrossRef]

102. Sadriev, A.R.; Mustafina, O.N.; Lukishina, L.V.; Anisimova, T.Y. Evolution of innovative approaches to improving the energy efficiency in power generation, transmission and consumption. Int. J. Appl. Eng. Res. 2015, 10, 41066-41071.

103. Russian Export Center. Available online: https://www.exportcenter.ru/en/on11.08.2019 (accessed on 22 April 2021).

104. OECD. Guidelines for Collecting and Interpreting Innovation Data, Oslo Manual, 3rd ed.; OECD: Paris, France, $2005 ;$ pp. 29-103. Available online: https:/ / ec.europa.eu/eurostat/documents/3859598/5889925/OSLO-EN.PDF (accessed on 22 April 2021).

105. Galeotti, M.; Salini, S.; Verdolini, E. Measuring environmental policy stringency: Approaches, validity, and impact on environmental innovation and energy efficiency. Energy Policy 2020, 136, 111052. [CrossRef]

106. Irandoust, M. On the causality between energy efficiency and technological innovations: Limitations and implications. Int. J. Green Energy 2019, 16, 1665-1675. [CrossRef]

107. Caramizaru, A.; Uihlein, A. Energy Communities: An Overview of Energy and Social Innovation; Publications Office of the European Union: Luxembourg, 2020.

108. Federal State Statistic Service, Russian Federation, 2017. Available online: http://www.gks.ru/wps/wcm/connect/rosstat_ main/rosstat/en/main/ (accessed on 12 December 2017).

109. Ahmed, U.; Mozammel, S.; Zaman, F. Impact of Ecological Innovation, Entrepreneurial Self-Efficacy and Entrepreneurial Orientation on Environmental Performance and Energy Efficiency. Int. J. Energy Econ. Policy 2020, 10, 289. [CrossRef]

110. Pan, X.; Ai, B.; Li, C.; Pan, X.; Yan, Y. Dynamic relationship among environmental regulation, technological innovation and energy efficiency based on large scale provincial panel data in China. Technol. Forecast. Soc. Chang. 2019, 144, 428-435. [CrossRef]

111. Yang, Z.; Shao, S.; Yang, L.; Liu, J. Differentiated effects of diversified technological sources on energy-saving technological progress: Empirical evidence from China's industrial sectors. Renew. Sustain. Energy Rev. 2017, 72, 1379-1388. [CrossRef]

112. Narayan, P.K.; Smyth, R. Electricity consumption, employment and real income in Australia evidence from multivariate Granger causality tests. Energy Policy 2005, 33, 1109-1116. [CrossRef]

113. Borenstein, M.; Hedges, L.V.; Higgins, J.P.; Rothstein, H.R. A basic introduction to fixed-effect and random-effects models for meta-analysis. Res. Synth. Methods 2010, 1, 97-111. [CrossRef] [PubMed]

114. Spearman, C. The proof and measurement of association between two things. Am. J. Psychol. 1904, 15, 88-93. [CrossRef]

115. Proskuryakova, L.; Filippov, S. Energy Technology Foresight 2030 in Russia: An Outlook for Safer and More Efficient Energy Future. Energy Procedia 2015, 75, 2798-2806. [CrossRef]

116. Pang, D.; Su, H. Determinants of energy intensity in Chinese provinces. Energy Environ. 2017, 28, 451-467. [CrossRef]

117. Lazhentsev, V.N. Theoretical Results of Research on Spatial and Territorial Development (on Examples of the North of European Russia). Econ. Reg. 2015, 4, 21-29.

118. Ratner, S.V.; Ratner, P.D. Regional energy efficiency programs in Russia: The factors of success. Region 2016, 3, 71-87. [CrossRef]

119. Crescenzi, R.; Jaax, A. Innovation in Russia: The Territorial Dimension. Econ. Geogr. 2016, 93, 66-8117. [CrossRef]

120. Sbia, R.; Shahbaz, M.; Hamdi, H. A contribution of foreign direct investment, clean energy, trade openness, carbon emissions and economic growth to energy demand in UAE. Econ. Model. 2014, 36, 191-197. [CrossRef]

121. Stanisic, N. Do foreign direct investments increase the economic growth of Southeastern European transition economies? South East. Eur. J. Econ. 2008, 1, 29-38.

122. Jin, M.; Tang, R.; Ji, Y.; Liu, F.; Gao, L.; Huisingh, D. Impact of advanced manufacturing on sustainability: An overview of the special volume on advanced manufacturing for sustainability and low fossil carbon emissions. J. Clean. Prod. 2017, 161, 69-74. [CrossRef]

123. Laurens, P.; Le Bas, C.; Lhuillery, S.; Schoen, A. The determinants of cleaner energy innovations of the world's largest firms: The impact of firm learning and knowledge capital. Econ. Innov. New Technol. 2017, 26, 311-333. [CrossRef]

124. Viesi, D.; Pozzar, F.; Federici, A.; Crema, L.; Mahbub, S. Energy efficiency and sustainability assessment of about 500 small and medium-sized enterprises in Central Europe region. Energy Policy 2017, 105, 363-374. [CrossRef]

125. Mustafina, O.; Melnik, A.; Sadriev, A. Features of formation of the system of innovative development of the industrial enterprise. Int. J. Appl. Eng. Res. 2015, 10, 39398-39403.

126. Melnik, A.N.; Lukishina, L.V.; Sadriev, A.R. Formation of the system of indicators to assess the impact of energy efficiency on the innovative development of the enterprise. Int. J. Appl. Eng. Res. 2015, 10, 40991-40997.

127. Gerstlberger, W.; Præst Knudsen, M.; Stampe, I. Sustainable development strategies for product innovation and energy efficiency. Bus. Strategy Environ. 2014, 23, 131-144. [CrossRef]

128. International Energy Agency. 2017. Available online: http://ec.europa.eu/eurostat/statistics-explained/index.php/The_EU_in_ the_world_-_energy (accessed on 12 December 2017).

129. Hielscher, S.; Seyfang, G.; Smith, A. Community Innovation for Sustainable Energy; CSERGE: Norwich, UK, 2011.

130. Sun, H.; Edziah, B.K.; Sun, C.; Kporsu, A.K. Institutionsal quality, green innovation.and energy efficiency. Energy Policy 2019, 135, 111002. [CrossRef] 